\title{
The Impact of the 2007-09 Credit Crunch on the Funding of Public Sector Infrastructure in the UK
}

UDK: 35:336.02 (292.422)

\author{
Stephen J. Bailey \\ Division of Public Policy, Caledonian Business School \\ Glasgow Caledonian University \\ S.J.Bailey@gcal.ac.uk \\ Darinka Asenova \\ Division of Accounting, Finance \& Risk, Caledonian Business School \\ Glasgow Caledonian University \\ D.Asenova @gcal.ac.uk
}

\section{ABSTRACT}

The 2007-09 credit crunch has not only created problems for the UK's public finances in meeting the costs of bailing out commercial banks and dealing with recession but also for providing better public services. This paper analyses the causes of the credit crunch, government policies to address it and its impact on the financing of new public sector infrastructure in the UK. It finds that provision of new public sector infrastructure and related services has been adversely affected by the impact of the credit crunch on Private Finance Initiatives (PFIs). Commercial banks are now generally only willing to lend to replace collapsed PFI bond financing if new PFI contracts reduce financial risks. By such means, PFls can be expected to survive but within an increasingly diverse mixture of procurement methods.

Key words: credit crunch, bank bailouts, PFIs/PPPs, public debt, public infrastructure

JEL: Financial Crisis (G01),

Government Policy and Regulation (G38) 
Stephen J. Bailey, Darinka Asenova

The Impact of the 2007-09 Credit Crunch on

the Funding of Public Sector Infrastructure in the UK

\section{The Credit Crunch}

The "credit crunch" refers to the collapse in bank lending as the cost of (both retail and wholesale inter-bank) credit became prohibitively expensive or simply unavailable during 2007-09. It owes its origins to lax regulatory regimes for banks, weak central bank safety nets for banks facing liquidity problems, growth of the much less heavily regulated shadow banking system, rapid innovation in financial products as banks competed aggressively for business, and the increasingly substantial international movements of capital.

Financial innovation was encouraged by banks and other financial institutions paying substantial annual bonuses to their directors and other employees to reward increased short-term sales of new financial products. Enjoying increased annual dividend payments financed by the resulting rapid expansion of bank turnovers and profits, shareholders did not question the long-term sustainability of such innovation. In combination, these developments resulted in the systemic failure of the financial services industry to abide by fiscal rectitude and prudential lending and borrowing.

Bank failures, recessions and credit crunches are not new (Klein and Shabbir 2006). What was new for the 2007-09 credit crunch was the increasing use of "securitization", whereby banks and other financial institutions packaged together mortgage debts and sold them on to other financial institutions both in their home countries and abroad. This included the "sub-prime mortgages" later subject to high default rates in the USA, UK and elsewhere.

Mortgages became increasingly large multiples of house-buyers' incomes and, with ever-lower cash deposits being required from borrowers, ultimately led to $100+\%$ mortgages. This ongoing expansion of mortgage debt was further accelerated by self-certification by borrowers themselves of their ability to repay debt, few banks carrying out checks. Additionally, more mortgages were being used for speculative buy-to let properties and homes were increasingly being re-mortgaged for non-residential purchases such as cars and foreign holidays.

Original lenders took the view that it didn't really matter if borrowers couldn't make mortgage payments because rising house prices meant that such borrowers could always either refinance their mortgages or pay them off by selling their houses at inflated prices. Moreover, loan originators quickly sold sub-prime loans to other financial institutions which, in turn, repackaged and sold them to investors as innovative financial products (e.g. collateralised 
debt obligations) paying higher rates of interest than offered by banks. Such financial innovation went hand-in-hand with the growth of non-bank financial institutions, these being less regulated than banks.

Put simply, in pursuit of high profits, banking regulators, directors of banks and shareholders had allowed banks to expand too rapidly and to buy and sell exotic investments (including mortgage-backed bonds) that they themselves poorly understood. There was insufficient financial transparency and poor appreciation of the increasingly risky nature of banking operations, banks rapidly moving from traditional (relatively safe) retail banking into (higher risk) investment banking.

Banks had become reckless in their operations, due diligence being largely abandoned in the highly competitive scramble for higher turnovers and increased market shares. The risks associated with the extent of securitisation were unclear and the banks had no clear overview of their total risk exposure because of the failings of the ratings agencies (Jones, 2008). Investors who thought they were holding high-grade debt (rated AAA by the credit-ratings agencies) became exposed to rising rates of default in the USA sub-prime mortgage market.

Globalisation of financial markets had enabled investors in other countries to buy this "toxic debt" and banks, pension funds, insurance companies and other financial institutions across the globe became increasingly exposed to risk of payment default on the part of debtors. They had bought that debt to diversify their financial portfolios and so supposedly reduce risk, being less exposed to a recession in their own countries. In practice, their exposure to financial risk was increased by the globalisation of financial markets, these cross-border investments acting as a "transmission mechanism" for recession to spread like a virus from one country to another - the collapse of Icelandic banks in late 2008 being a case in point.

Banks in most EU member states had also pursued securitisation. They had become too highly levered, predominantly financing their mortgage business not from their own deposits but, instead, by borrowing short-term on secondary markets to lend long-term to their mortgagees. As loans from other banks and financial institutions dried up, banks that had depended upon the secondary markets to refinance their loans experienced very severe cash flow problems, for example Northern Rock (Boakes, 2008).

Put simply, the credit crunch was the result of governments' deregulation of lending without introduction of sufficiently rigorous self-regulation, without 
Stephen J. Bailey, Darinka Asenova

The Impact of the 2007-09 Credit Crunch on

the Funding of Public Sector Infrastructure in the UK

appropriate governance arrangements and without sufficient scrutiny of the risk models employed.

\section{The Response of Governments to the Credit Crunch}

The highly-speculative short-term financial model adopted by the senior executives of many banks to win them large annual bonuses has been criticised for gambling long-term with other people's money (i.e. their depositors and shareholders). Now national governments could similarly be criticised for being reckless with future tax-payers' money as they borrow increasingly large proportions of GDP in order to "bail out" those heavily indebted banks and other private sector organisations.

The International Monetary Fund (IMF) calculated the ratios of fiscal stimulus relative to GDP based on the initial measures announced by national governments in 2008 as: UK 1.5\%, USA 4.9\%, Japan 9.1\%, Germany 3\% and France $1.15 \%$. Subsequently, in early 2009 , the UK government began to exchange mortgage bonds (i.e. the toxic debt) for government bonds, take majority shareholdings in banks and insure bank loans against default.

The IMF calculated these additional measures increased the UK's ratio to $19.8 \%$, as of February 2009, by far the highest ratio in the G20 countries (the USA's rose to "only" 6.8\%). These ratios increase as further debt-financed measures are announced and as GDP falls. The European Commission (EC) has forecast falls in GDP in most EU member states in 2009, including the UK by $3.8 \%$. The IMF forecasts similar falls in the USA and elsewhere. The accelerating costs to the public purse of these measures raise questions about fiscal prudence, especially in the UK.

Between 1997 and 2007 UK central government budgets had been based on its much-vaunted fiscal rectitude principle of "prudence for a purpose". Response to the credit crunch now seems to be "imprudence for a purpose". If the hoped-for higher levels of economic growth are not forthcoming, a deepening and prolonged recession/depression will make what had already been a long-term "structural gap" between (higher) government expenditures and (lower) revenues much greater (Bailey, 2004). This will exacerbate any losses the government (and, ultimately, taxpayer) incurs on its ongoing purchases of increasingly large proportions of bank shares, swaps of government 
bonds for toxic mortgage-backed bonds, guarantees of bank loans on both wholesale and retail money markets, etc., (Goodhart, 2009). The values of mortgage-backed bonds subsequently fell significantly below what the government paid for them.

In buying up very large proportions of shares in several UK banks and introducing special liquidity schemes, the government has effectively allowed banks to nationalise their rapidly increasing losses whilst privatising their profits. Largely incalculable financial risks have been transferred from the private to the public sector, much the same occurring in other countries including the USA. This hardly seems prudential on the part of national governments and it creates moral hazard by setting a precedent for future taxpayer bailouts of highly irresponsible bank lending. Justifying the current high-risk fiscal largesse by arguing that doing nothing would be more costly for the future health of the economy is an act of faith in the success of the ever-increasing bank bailouts and fails to address how the huge increases in government debt will be repaid.

Repayment will be even more difficult if interest rates rise from their very low-to-zero levels of early 2009 and by the downgrading of sovereign debt (used to refinance loans) by ratings agencies. The creditworthiness of at least ten countries had already been brought into question during late 2008, especially those holding Icelandic sovereign debt, Iceland itself being in receipt of emergency IMF loans. The increased cost of insuring against default (via credit default swaps and collateralised debt obligations) made sovereign debt issued by Argentina, Greece, Ireland, Kazakhstan, Serbia, South Korea and the Ukraine relatively unattractive by the end of 2008, notwithstanding the higher interest rates on offer. The sovereign debt of Greece and Spain was downgraded in early 2009, with Ireland, Portugal and other countries possibly soon following.

The UK central government has abandoned its own fiscal rules, namely the "golden rule" (borrow only for capital, not current, expenditure) and the "sustainable investment rule" (net public debt no greater than $40 \%$ of GDP). Its own figures show that net public debt exceeded $50 \%$ of GDP in January 2009 and forecast it to peak at almost $60 \%$ by 2012/13. Nevertheless, this still seems low compared with those EU eurozone countries rapidly approaching breaches of the Stability and Growth Pact. In January 2009 the EC forecast 15 of them to be in breach of the Pact in 2009. It also forecast budget deficits to average $4.4 \%$ in 2010 and government debt to average $76 \%$ of GDP, both well above the Pact's ceilings of $3 \%$ and $60 \%$ respectively (Fingland and Bailey 2008). 
Stephen J. Bailey, Darinka Asenova

The Impact of the 2007-09 Credit Crunch on

the Funding of Public Sector Infrastructure in the UK

It is notable that, whilst the UK central government is now guaranteeing bank bonds, it does not guarantee bonds issued by local governments (Bailey et al., 2009). It also does not guarantee the safety of councils' bank deposits outside the UK, many having deposited large sums of money in Icelandic and other off-shore banks because of the higher rates of interest they offered on deposits compared with UK banks. In doing so, however, they forsook the protection afforded for deposits in UK banks. With the benefits of hindsight, this was highly imprudent lending (i.e. in the form of bank deposits) and contrasts sharply with the requirement for prudence in respect of their borrowing.

\section{Implications for the Provision of Public Sector Infrastructure in the UK}

The provision of public sector infrastructure and related services in the UK has relied increasingly on use of the Private Finance Initiative (PFI) since the early 1990s. Explained in detail in an earlier issue of this journal (McQuaid and Scherrer, 2008), it is a form of Public-Private Partnership (PPP) intended to achieve value for money and reduce the need for the accumulation of public sector debt.

Its growing use can also be explained by the increasing availability of easy money from banks and capital markets during the sustained economic growth of the mid-to-late 1990s and early 2000s. By 2009, there were 860 signed PFI projects with capital value exceeding $£ 68$ billion, most of them being launched since 1997. Most of these projects (650) are in the operational phase (Timmins, 2009a).

In a typical PFI contract banks were initially providing 80 per cent and later on, with increased market confidence, up to 90 - 95 per cent of total capital requirement. During the 2007-09 credit crunch, global economic downturn and unprecedented multi-billion pound state bailouts of banks etc., the finance system moved from highly speculative lending to a drastic reduction of the availability of finance. The continued use of the PFI model to finance public service infrastructure became increasingly open to question.

In 2008, following the collapse of the capital markets, cheap corporate bond financing practically disappeared due to lower credit ratings of the insurers that guaranteed returns to investors (Stiff, 2008). The availability of cheaper bond financing is not likely return until recovery of the capital markets 
so, until then, bank finance remains virtually the only alternative. As banks became much more risk averse in their lending, it became much more difficult and more expensive to secure finance and this affected the number of planned projects reaching financial close of contracts. Thus, during 2008 only 34 projects' financing agreements were finalised, about half of the annual rate for the previous years (Timmins, 2009a).

HSBC, a commercial bank heavily engaged in lending to PFls before the credit crunch began restricting its lending for PFIs to short-term funding and now only lends to clients it knows and trusts them to repay those loans. RBS and HBOS, two other commercial banks, had also both been large PFI lenders prior to the credit crunch but RBS (now 70\% state-owned) subsequently scaled down its involvement and the takeover of HBOS by Lloyds TSB further reduced its willingness to lend to PFIs.

In addition to the drastic reduction of funding available from the banks, large-scale projects have experienced even more severe problems because banks' appetite for buying syndicated debt, which is a part of the total PFI debt, has been substantially reduced. This in turn increased the overall financing costs (O'Connor, 2008).

Since the beginning of 2009 some of the banks have been returning to the market but the availability of finance has been severely restricted by higher margins being required and much tougher lending conditions. The financial arrangements now tend to involve multiple investors, instead of only one or two banks and the duration of contracts has typically been reduced from 25-30 to 7-10 years. Moreover, banks are generally unwilling to finance more than $£ 30$ to $£ 50$ million on a single transaction and so are looking for other participants to provide the rest of the capital requirement (Timmins, 2009a). This means that the process of arranging PFI finance has become slower and more uncertain. Additionally, banks require credit risk to be passed to service providers and where possible, they have been looking for government guarantees in case of financial difficulties.

Additional challenges are expected with the introduction of new accounting standards. Since April 2009, due to the adoption of the International Financial Reporting Standards (IFRS) by the UK government, the accounting treatment of PFI projects changed and the majority of PFI projects now have to be entered on public sector balance sheets. Having previously been "off balance sheet", there has been speculation that this new accounting rule will remove 
Stephen J. Bailey, Darinka Asenova

The Impact of the 2007-09 Credit Crunch on

the Funding of Public Sector Infrastructure in the UK

the accounting and perhaps political driver for this procurement route at central and local government level.

\section{Impact on Public Services in the UK}

Local governments are responsible for providing most public services in the UK and they were already having to deal with demographic changes, ageing population, centrally-required efficiency savings and other financial cuts prior to the credit crunch (Anon, 2008a). Reflecting the public finance costs of dealing with the credit crunch (see above), the UK government announced further funding cuts in its April 2009 Budget. Municipalities' revenues have also been adversely affected by the reduced demand for some chargeable services, by falling asset sales and by diminishing receipts from developers caused by the slump in the housing market.

Furthermore, more than a hundred UK local authorities may lose the $£ 840$ million they deposited in the collapsed Icelandic banking system because of the lack of UK government protection (Anon, 2008b). The loss of these deposits could potentially affect the financial stability of these councils and their provision of services.

The financial difficulties faced by local and central government have direct implications for the provision of future roads, recycling plants, schools and hospitals which, in some cases, have effectively ground to a halt due to the failure of banks to invest in PFIs. A report by the NAO revealed that the Building Schools for the Future (BFS) programme, a version of PFI in England and Wales, was two years behind schedule and $£ 10$ billion over budget (McAlpine, 2009). The program effectively stalled, only two projects being signed during the previous six months (Hayman, 2009).

Other sectors have also been affected. The National Health Service (NHS) hospital rebuilding program depended entirely on PFI and there was no "plan B" for meeting the financial requirement (Curtis, 2009). In 2008, twelve major PFI hospital projects were abandoned due to lack of finance. In March 2008, it was announced that the plans for financing a PFI hospital for Maidstone and Tunbridge NHS Trust in Kent through corporate bonds issue had to be abandoned and the client had to revert to more expensive bank finance $\left(\mathrm{O}^{\prime} \mathrm{C}\right.$ Connor, 2008). Similarly, the largest PFI ( $£ 1$ billion) intended to provide the Royal Air Force (RAF) with a fleet of refuelling tankers faced similar problems and its 
financial structure has been under consideration. Doubts have been expressed about the upgrade of the M25 motorway around London and of modernisation of the Jubilee, Northern and Piccadilly London Underground lines (Leftly, 2009).

By contrast, recent reports in the media indicate that a version of PFI used by the Department of Health in England and Wales known as Express Lift has proved to be better suited to the current financial environment (Timmins, 2009b). These are typically smaller projects, in the range of $£ 3$ to $£ 7$ million, which means that the arrangement of the capital requirement is not as problematic as for large-scale PFls. The Express Lift model involves a joint venture between the primary care trusts (and sometimes local authorities) which own 40 per cent of the equity stake, and the private companies for the purpose of financing, building and running GP (i.e. family doctor) surgeries and other health facilities over 20 years. Under Express Lift there is a framework contract with seven selected private sector consortiums which have quasimonopoly power over the entire market. NHS primary care trusts are no longer required to prepare and conduct a full EU-wide tendering process as they can choose any one from these seven consortia. This means a considerable speeding up of the procurement and negotiation time scale from a typical two years to several months, reducing the excessive PFI bidding costs.

In Scotland, public service provision has been affected by the tough UKwide economic conditions and eight Scottish local authorities may lose the $£ 45$ million deposited in Icelandic banks (Fegan, 2008; Gunn, 2008). Additionally, Scottish local authorities are particularly badly affected by the Scottish government abandoning the use of PFIs for new projects in 2007.

The Scottish government introduced what was intended to be a different form of Public Private Partnership vehicle called the Scottish Futures Trust (SFT) as an alternative to PFI. However, the SFT has so far failed to commission new infrastructure projects, leading to protracted delays in the delivery of new public services and to heavy criticism that it is not a workable alternative to PFIs (Scottish, 2009).

The apparent failure of the SFT has caused further uncertainty in the building industry and the housing market which have been virtually at a standstill for the last two years. The lack of infrastructure projects exacerbated the losses of many private sector companies. There have been calls from various political parties and from the industry for the Scottish government to abandon the SFT 
Stephen J. Bailey, Darinka Asenova

The Impact of the 2007-09 Credit Crunch on

the Funding of Public Sector Infrastructure in the UK

and to revert back to the PFI which, despite its problems, has a proven delivery track record (Gunn, 2008; Glackin, 2009).

Compounding this widespread criticism, financial industry representatives have also expressed their lack of confidence in the SFT model. In the absence of projects being put out to tender by the SFT, experienced PFI teams at banks, construction and consultancy companies are being dismantled or moved to other parts of the country, leading to loss of expertise. Not surprisingly, the Scottish government has been accused of "tunnel vision" (Glackin, 2009).

Another consequence of the Scottish government's abandonment of PFIs is that Scotland fails to benefit from the UK Treasury's additional financial support for provision of public sector infrastructure. This support was introduced in March 2009 and applies only to PFI schemes.

\section{UK Government Support for PFI Projects}

As explained above, the PFI program in all service sectors has been affected by the funding crisis as capital markets collapsed and banks refused to lend at reasonable rates. In January 2009, it became clear that the government would underwrite some larger scale PFI transactions. In order to assure investors that taxpayers will shoulder some of the costs, the UK government was already underwriting some shorter-term and lower-scale transactions.

Determined to pursue the PFI option, in March 2009 the UK government announced taxpayers' money would be used to rescue PFI projects in the form of bridging loans of between $£ 1$ billion and $£ 2$ billion in 2009-10 (Hayman, 2009; Hencke, 2009, Milmo et al. 2009). It wants private finance to continue to play an important role in public service provision, particularly in the light of the announced "cash freeze" in public sector capital expenditure from 2011. This is the case even though the IFRS requires PFIs now to be on the public sector balance sheet.

The UK government's Infrastructure Finance Unit (dubbed "the Treasury bank" now lends directly to PFI projects and also indirectly to them via government-owned banks. Although initially restricting its support to bridging loans, the Treasury bank can also provide the full amount of senior debt required by a PFI project. It is also considering other ways of helping finance stalled PFI projects by, for example, underwriting bank debt and providing equity bridging loans. 
This finance for stalled PFIs is part of broader measures aiming to stimulate the economy and create jobs during the recession. Public sector bodies have to apply to the UK Treasury through their government departments for financial support. Loans must be repaid when future lending conditions improve and the projects are refinanced. The Treasury can also re-sell the loans when the market recovers.

According to the UK Treasury, 110 major PFI infrastructure projects worth an estimated $£ 13$ billion then in the pipeline would be saved from collapse by this support. While the Treasury is willing to provide co-funding, it will provide the full financial requirement for some projects if necessary. Priority is given to waste recycling schemes with a view of helping UK avoid the heavy EU fines it will incur if it misses the mandatory targets to half landfill use by 2013 (Hencke, 2009). The money also provides financial help for ten PFI hospital projects delayed due to lack of finance.

This support has been met with political opposition because, as noted above, PFI schemes are now reflected in government accounts. The government has been criticized for removing the private element from PFI. According to the Treasury spokesman of the Conservative party Phillip Hammond "if you take the private finance out of PFI, you haven't got much left....and if you transfer the financial risk back to the public sector, then that has to be reflected in the structure of the contract" (Timmins, 2009a, p. 11).

Similar criticisms have also been made by the general secretary of the Trades Union Congress (TUC). He noted that such an arrangement will allow the privatisation of the profits and the nationalisation of the losses (Leftly, 2009). The paradox is that many PFIs are financed by HBOS and RBS. Thus, the government is subsidising the contracts in order to guarantee returns to the banks rescued with tax payers' money. Future generations are likely to face repayment of huge national debt and cuts in public spending while, at the same time, having to continue payments to the banks that have been bailed out.

The counter-argument is that even if the bulk of the capital requirement comes from the Treasury, private sector companies are still required to provide equity capital which takes most of the risk. As a financier, the government has to conduct rigorous risk assessment, due diligence and impose the financial discipline that is normally introduced by the banks. There is also a possibility for a conflict of interests when the UK central government acts as both a 
Stephen J. Bailey, Darinka Asenova

The Impact of the 2007-09 Credit Crunch on

the Funding of Public Sector Infrastructure in the UK

funder and a purchaser, even if the purchasing is conducted through local government or NHS trusts.

\section{Future Prospects for the PFI Model in the UK}

In March 2009 it was announced that the UK Treasury will undertake a six-month review of PFI which will assess the future of the scheme. While the outcome of the review is uncertain, the expectation is that it is likely to propose some alterations and readjustments in line with changed market conditions (Leftly, 2009).

The future expansion of public services appears very heavily constrained by the UK government's April 2009 Budget's medium-term plans of only 0.7 per cent annual growth of public expenditure and by increasingly substantial repayments of long-term debt. This will encourage the search for innovative approaches which build on the advantages of PFI. It has been argued that the $\mathrm{PFI}$ process has contributed to public sector learning and that, if possible, government policy should ensure the continuation of the benefits brought by it (PwC, 2008). According to PwC, the key beneficial outcomes of PFI include:

- Focus on outputs/outcomes rather than inputs;

- More rigorous risk/cost analysis;

- Optimal allocation of risk;

- Synergies and integration of design/construction/ operation/maintenance;

- Whole-life costing;

- Comprehensive competition across all elements of the project;

- Long-term performance management;

- Whole-contract management and hand-back of the asset in contractually agreed condition.

A return to traditional procurement and financing practices could lead to a relaxation of these PFI disciplines. There is clearly a need to retain those disciplines by utilising techniques such as comprehensive risk assessment and by paying attention to, and providing incentives for, reduction of life-cycle costs. 
The public sector should also consider carefully the evaluation of the new PFI models (such as the BSF and Lift models noted above and which involve public sector equity) against the new risks associated with them. Particular attention should be given to maintaining the focus on risk analysis and allocation, as well as the due diligence disciplines which, in a typical PFI, are introduced by lenders, monocline insurers and ratings agencies.

Prior to adoption of the new IFRS and the changes to the accounting treatment of PFls, their off-balance-sheet treatment had been a pre-requisite for the award of PFI credit and was used as a proxy indicating sufficient transfer of risk to the private sector. However, other criteria can be used to ensure sufficient risk transfer and the impact of bringing PFI liabilities on-balancesheet depends on the model adopted for the distribution of PFI credits.

Changes to the accounting treatment of PFIs should have little or no impact for central government projects, the majority of which have been classified as on-balance-sheet. However, off-balance-sheet borrowing by the UK government stood at almost $£ 20$ billion by early 2009 . This had been facilitated by turning public sector organisations into not-for-profit companies independent of central government. Examples are Network Rail (the company owning the UK's railway lines and signalling systems), the BBC Trust and Welsh Water (which provides water and sewerage services in Wales). Their borrowing does not affect governmental borrowing limits because, technically, they are deemed by the UK's Office of National Statistics not to be in the public sector. Together with the off-balance-sheet treatment of PFI liabilities, this effectively under-reports public sector debt in the UK and so qualifies comparison of its past debt-to-GDP ratios with other countries (see above).

The not-for-profit format has also been proposed for the state-owned Post Office and Royal Mail in order to raise private finance from capital markets to pay for investment in new technology without affecting governmental borrowing limits or requiring full privatisation or use of PFIs. Given that PFIs are now on the public sector balance sheet, it could be expected that the not-for-profit ownership structure will be more widely adopted.

\section{Conclusions}

Even before the credit crunch PFIs were criticised for being more expensive than direct government borrowing for financing provision of public service 
Stephen J. Bailey, Darinka Asenova

The Impact of the 2007-09 Credit Crunch on

the Funding of Public Sector Infrastructure in the UK

infrastructure. The UK government's response to the credit crunch has now reversed the very risk transfer that was supposed to more than compensate for those higher interest rate costs. This reversal is the result of the government now financing banks so they can on-lend to PFls at higher interest rate mark-ups and the debt relating to that on-lending is effectively guaranteed by the government.

Despite these and other criticisms, the PFI can be expected to survive in the long term. First, a huge financial services industry has been created round it in the City of London. Second, the Labour Government is providing shortterm support and is willing to consider longer-term measures until bank credit becomes much more easily available. Third, the Conservative Party will almost certainly maintain that support if it wins power at the next general election. Fourth, capital markets can reasonably be expected to recover, the only real doubt being precisely when. Fifth, as noted above, the standard PFI model can be and is being restructured so as to strengthen the advantages and minimise the disadvantages. Certainly, other forms of Public-Private Partnerships are already in use in the UK and other countries.

Together with use of conventional procurement, increased adoption of the not-for-profit format, direct borrowing by local governments issuing their own bonds, and other means, it could be expected that an increasingly diverse mixture of various procurement methods will be identified across the different parts of the UK public sector, adapted to the mixed, pluralistic requirements of the various service programmes seeking capital procurement. 


\section{Stephen J. Bailey, Darinka Asenova \\ The Impact of the 2007-09 Credit Crunch on the Funding of Public Sector Infrastructure in the UK}

Stephen J. Bailey is Professor of Public Sector Economics at Glasgow Caledonian University, UK. He has published widely in the fields of public sector economics, local government economics and public finance including journal articles, book chapters and books dealing with intergovernmental grants, local taxation, borrowing, charges, public choice theory and local government reform etc. He has been a guest lecturer at universities in Czech Republic, Denmark, Finland, New Zealand, Poland, Slovenia, South Korea, and Sweden. Consultancies include the Glasgow Development Agency, the Council of Europe, the World Bank and OECD, the Museums and Galleries Commission, the Chartered Institute of Public Finance and Accountancy and UNISON. He has also been an academic adviser to the Audit Commission and the Accounts Commission.

Dr. Darinka Asenova is a Senior Lecturer in the Division of Accounting, Finance and Risk at Glasgow Caledonian University, UK. She holds an MSc degree in Physics from Sofia University, BA in Business and a PhD from Glasgow Caledonian University. Dr. Asenova has a multidisciplinary background which includes risk management, public policy, public and private finance. Her current research interests and publications are in the areas of financial risk management in novel methods for financing capital projects, public/private sector risk management, accountability, as well as various aspects of contemporary public policy. She teaches a range of undergraduate and postgraduate courses in risk management.

\section{Bibliography}

- Anon, (2008a): How the Financial Crisis will affect Local Government, The Guardian, 8 October.

- Anon, (2008b): Council not "reckless" with Cash, BBC News, Available at: http://news.bbc.uk/1/hi/uk politics, Accessed on 10 October.

- Bailey S. J. (1999): Local Government Economics: Principles and Practice. London: Palgrave Macmillan.

- Bailey S. J. (2004): Strategic Public Finance. London: Palgrave Macmillan.

- $\quad$ Bailey S. J., Asenova D. and Hood J (2009): "Making More Use of Local Government Bonds in Scotland? « Public Money and Management Vol 29 No 1 pp11-18.

- Boakes K (2008): Reading and Understanding the Financial Times. London: FT Prentice Hall.

- Curtis, P. (2009): Government may have to take on Risk of PFI Deals, The Guardian, 27 January.

- Fegan, C. (2008): Scots Councils' £40m Invested in Icelandic Banks at Risk, The Herald, 11 October.

- $\quad$ Fingland L. and Bailey S. J. (2008): The Stability and Growth Pact: Its Credibility and Sustainability, Public Money and Management Vol 28 No 4 pp223-30. 
Stephen J. Bailey, Darinka Asenova

The Impact of the 2007-09 Credit Crunch on

the Funding of Public Sector Infrastructure in the UK

- Glackin, M. (2009): Builders Call for English System, The Sunday Times, 12 April.

- Goodhart C. A. E. (2009): The Regulatory Response to the Financial Crisis. Cheltenham: Edward Elgar Publishing

- Gunn, C. (2008): Salmond's HBOS Waiting Game, The Sunday Post, 12 October.

- Hayman, A. (2009): £13 Billion Rescue Plan for PFI Projects, Regeneration \& Renewal, 9 March, p. 5.

- Hencke, D. (2009): Treasury Rescues Big Building Projects with $£ 2$ billion Injection, The Guardian, 3 March, p. 12.

- $\quad$ Klein L. R. and Shabbir T. (2006): Recent Financial Crises. Cheltenham: Edward Elgar Publishing.

- Leftly, M. (2009): Treasury's New Man to Review the Future of Broke' PFI Schemes, The Independent on Sunday, 22 March, p. 78.

- McAlpine, J. (2009): Schools Suffer Over PFI Mess, The Sunday Times, 22 February.

- McQuaid, R. W., and Scherrer W. (2008): Public Private Partnerships in the European Union: Experiences in the UK, Germany and Austria, Uprava 2008, VI, 2, p.7-34.

- Milmo, D., Inman, P., and Durrani, A. (2009): A Bridge too far for PFI Schemes, The Guardian, 18 April.

- O'Connor, S. (2008): Hospital Project Hit by US Bond Insurers Crisis, Financial Times, 3 March.

- PwC, (2008): The Value of PFl: hanging in the Balance Sheet?, PricewaterhouseCoopers Public Sector Research Centre, Available at:

http://www.pwc.com/extweb/industry.nsf/docid/e418cebd9326ab60852572ce0034121f/ \$File/The Value of PFI.pdf, Accessed on 15 April 2009.

- Scottish, M. (2009): SNP's Dogma is Depriving Scotland of PFI Millions, The Scotsman, 4 March.

- Stiff, P. (2008): Hospital and Road financing Squeezed by Credit Crunch, The Times, 10 March.

- $\quad$ Timmins, N. (2009a): Projects Seek Partners, Financial Times, 24 February, p. 11.

- Timmins, N. (2009b): Seven Groups set to win NHS Building Deals, Financial Times, 13 March, p. 2. 


\section{POVZETEK}

\section{VPLIV POSOJILNEGA KRČA NA FINANCIRANJE INFRASTRUKTURE JAVNEGA SEKTORJA V ZDRUŽENEM KRALJESTVU VELIKE BRITANIJE IN SEVERNE IRSKE (VB) V LETIH 2007-2009}

"Posojilni krč» je nastal v letih 2007 do 2009 kot zastoj bančnih posojil, ker so se stroški posojil prebivalstvu in stroški medbančnih posojil pretirano povišali ali pa posojila preprosto niso bila dostopna. Njegov izvor je bil $v$ ohlapnem pravnem redu za banke in $v$ neustreznem varnostnem sistemu centralne banke za odkrivanje bank z likvidnostnimi problemi; veliko manj strogo regulirani bančni sistem $v$ senci se je hitro razvijal, kot posledica agresivne bančne konkurence so se banke zatekale $k$ novim finančnim storitvam, ob tem pa se je vedno bolj obsežno prelival mednarodni tok kapitala. Preprosto povedano, posojilni krč je bil rezultat vladnih deregulacij kreditiranja brez uvedbe dovolj stroge samoregulacije, brez ustreznih postopkov upravljanja in brez zadostnega nadzora uporabljenih modelov tveganja.

Med letoma 2007 in 2009 so državne proračune VB potrjevali po tedaj splošno poveličevanem načelu "previdnost z namenom ". Zdaj pa se zdi, da je bil odziv na posojilni krč "neprevidnost z namenom «. Ko je vlada nakupila velik delež delnic $v$ raznih bankah VB in uvedla posebne likvidnostne sheme, je dejansko dovolila bankam, da so podržavile svoje hitro rastoče izgube in hkrati privatizirale svoje dobičke.

Pretežno neocenljiva finančna tveganja so se tako prenesla iz zasebnega $v$ javni sektor, podobno kot se je to zgodilo $v$ drugih državah. Tako ravnanje državnih vlad bi težko označili kot previdno, saj povzroča moralni hazard in ustvarja presedan za prihodnje finančne injekcije davkoplačevalcev za zelo neodgovorno izvajanje bančnih posojilnih poslov. Opravičevanje sedanje izredno tvegane javnofinančne radodarnosti $z$ argumenti, da bi bilo za zdravje gospodarstva $v$ prihodnosti dražje, če ne bi storili nič, pomeni zaupanje $v$ uspeh vedno večjih bančnih finančnih injekcij in zanemarja vprašanje, kako bodo poplačani velikanski porasti državnega dolga.

Vlada VB je opustila svoja lastna javnofinančna pravila, namreč "zlato pravilo" (posojaj samo za kapitalske, ne tekoče izdatke) in "vzdržno investicijsko pravilo" (neto javni dolg naj ne bo večji kot $40 \%$ BDP). Številke, ki jih je sama objavila, kažejo, da je $v$ januarju 2009 neto javni dolg presegel 
Stephen J. Bailey, Darinka Asenova

The Impact of the 2007-09 Credit Crunch on

the Funding of Public Sector Infrastructure in the UK

$50 \%$ BDP in napovedujejo, da se bo povzpel do skoraj $60 \%$ BDP $\vee$ letih 2012/13.

Posojilni krč v letih 2007-09 je ne samo ustvaril probleme $v$ javnih financah za pokrivanje stroškov finančnih injekcij poslovnim bankam in pri poslovanju $v$ recesiji, ampak je tudi zavrl zagotavljanje boljših javnih storitev. Zlasti je bilo oskrbovanje nove infrastrukture javnega sektorja in povezanih storitev okrnjeno z učinki posojilnega krča na pobude za zasebno financiranje (PFI). Kapitalski trgi so postali veliko manj naklonjeni prevzemanju finančnih tveganj, povezanih s shemami PFI, vedno manjše je tudi povpraševanje po podjetniških obveznicah, ki se običajno uporabljajo za njihovo financiranje. Poslovne banke so pri odobravanju posojil pripravljene upoštevati financiranje z obveznicami le, če se o pogodbah PFI ponovno pogajajo in tako zmanjšajo finančna tveganja.

Po zlomu kapitalskih trgov $v$ letu 2008 je praktično izginilo poceni financiranje projektov PFI $s$ podjetniškimi obveznicami zaradi slabših ratingov zavarovateljev, ki so jamčili donose investitorjem. Financiranje $s$ cenejšimi obveznicami verjetno ne bo več dostopno do ponovne vzpostavitve kapitalskega trga, zato je ostalo bančno financiranje kot edina možnost. Ker so banke postajale vedno bolj previdne pri prevzemanju posojilnih tveganj, je zagotavljanje finančnih sredstev postajalo veliko težje in dražje, kar je prizadelo številne načrtovane projekte, ki so bili $v$ fazi finančne konstrukcije.

V začetku leta 2009 so se nekatere banke vrnile na trg, toda dostopnost finančnih sredstev je bila zelo omejena zaradi zahtevanih višjih bančnih marž in zaradi veliko strožjih posojilnih pogojev. Namesto ene ali dveh bank finančni posli zdaj običajno zajemajo več investitorjev, trajanje kreditiranja se je skrajšalo od 25 do 30 let na 7 do 10 let. Na splošno banke niso pripravljene financirati več kot 30 do 50 milijonov funtov pri eni transakciji in zato iščejo druge udeležence, ki bi zagotovili preostanek potrebnega kapitala. To pomeni, da je proces dogovarjanja financiranja investicij PFI postal bolj počasen in bolj negotov. Banke poleg tega zahtevajo, da se posojilno tveganje prenese na ponudnike storitev in iščejo državne garancije za primer finančnih težav.

V januarju 2009 se je razvedelo, da bo vlada VB prevzela nekaj obsežnejših transakcij PFI. Državni oddelek za financiranje infrastrukture (z drugim imenom "Banka zakladnica») zdaj posoja sredstva projektom PFI neposredno in tudi posredno prek bank v državni lasti. Čeprav je Banka zakladnica $v$ začetku omejevala podporo premostitvenim posojilom, lahko 
zdaj zagotovi tudi polni znesek prednostnih dolgov, ki je potreben za projekt PFI. Preverja tudi druge načine pomoči zastalim projektom PFI, tako da bi na primer prevzela bančni dolg in zagotovila premostitvena posojila za lastniški kapital.

Kot poroča Zakladnica VB, se bo s to pomočjo pred propadom rešilo 110 večjih PFI infrastrukturnih projektov, vrednih 13 milijard funtov. Medtem ko je Zakladnica pripravljena zagotoviti sofinanciranje, bo za nekatere projekte po potrebi zagotovila tudi vsa finančna sredstva. Prednost bodo imeli načrti recikliranja odpadkov, zato da bi pomagali VB, da se izogne kaznim EU, če ne bodo doseženi obvezni cilji razpolovitve odlagališč odpadkov v zemljo do leta 2013. Finančna pomoč naj bi se uporabila tudi za deset projektov PFI za izgradnjo bolnišnic, ki so zastali zaradi pomanjkanja finančnih sredstev.

Državna podpora je bila deležna političnega nasprotovanja, ker se sheme PFI zdaj odražajo $v$ državnem proračunu. Zlasti so kritizirali vlado, ker je iz PFI odstranila zasebni delež. Taka ureditev omogoča privatizacijo dobičkov in nacionalizacijo izgub. Paradoks je $v$ tem, da številne projekte PFI financirata HBIOS in RBS, poslovni banki, ki ju je rešila vlada VB. Tako vlada subvencionira pogodbe PFI, zato da zagotovi donose bankam, ki jih je rešila z denarjem davkoplačevalcev. Prihodnje generacije se bodo verjetno soočale s poplačilom velikanskega državnega dolga in z rezanjem javnih izdatkov, hkrati pa bodo morale še vedno plačevati bankam, ki so prejele finančne injekcije. Že pred posojilnim krčem so kritizirali projekte PFI, da so dražji kot neposredno posojanje vlade za financiranje izgradnje javne infrastrukture. Odziv vlade VB na posojilni krč je zdaj spremenil tveganje, ki naj bi povzročilo višje stroške obresti. Ta preobrat je rezultat sedanjega državnega financiranja bank, tako da lahko naprej kreditirajo PFI po višjih obrestni meri, za dolg, ki nastaja ob tem kreditiranju, pa dejansko jamči vlada.

Kljub tem in drugim kritikam lahko pričakujemo, da bo PFI na dolgi rok preživelo. Prvič se je $v$ Londonu ustvarila velika ponudba finančnih storitev. Drugič, laburistična vlada VB zagotavlja podporo v kratkem roku in je pripravljena razmisliti o dolgoročnih ukrepih, dokler bančna posojila ne postanejo veliko bolj dostopna. Tretjič, konzervativna stranka bo skoraj zagotovo nadaljevala to podporo, če pride na oblast pri naslednjih splošnih volitvah. Četrtič, kapitalski trgi si bodo po vsej verjetnosti opomogli, ostane samo vprašanje, kdaj se bo to zgodilo. Petič: standardni 
Stephen J. Bailey, Darinka Asenova

The Impact of the 2007-09 Credit Crunch on

the Funding of Public Sector Infrastructure in the UK

model PFI je mogoče preoblikovati in to se že dogaja, tako da se krepijo njegove prednosti in zmanjšajo slabosti.

Medtem pa finančne težave, s katerimi se soočajo načrti PFI lokalnih vlad in centralne vlade, neposredno vplivajo na izgradnje cest, naprav za recikliranje, šol in bolnišnic, ki so se $v$ nekaterih primerih ustavile zaradi nesposobnosti bank, da bi investirale $\vee$ PFI.

Alternativna možnost čakanju na oživitev kapitalskih trgov in projektov PFI je morda preoblikovanje organizacij javnega sektorja $v$ VB $\vee$ neprofitne združbe, neodvisne od države. Primeri so Network Rail (združba, ki je lastnica železnic in signalizacijskih sistemov $v$ VB), BBC Trust an Welsh Water (ki zagotavlja vodo in ločevanje odpadkov $\vee$ Walesu). Posojila teh združb ne zadevajo vladne omejitve kreditiranja, zato ker ju državni statistični urad tehnično ne obravnava kot del javnega sektorja.

Tako obliko je predlagala državna pošta, Post Office and Royal Mail, zato da bi pridobila zasebna finančna sredstva iz kapitalskih trgov za poplačilo investicij $v$ nove tehnologije, ne da bi zadela ob vladne omejitve kreditiranja ali da bi morala izvesti polno privatizacijo ali uporabo PFI. Glede na to, da so PFI del bilance javnega sektorja, bi lahko pričakovali, da se bo pogosteje privzemala struktura neprofitnega lastništva.

Zato lahko pričakujemo, da se bodo ob konvencionalnih oblikah oskrbe $s$ kapitalom vedno bolj uveljavljale najrazličnejše, nove metode oskrbe, kot so prevzemanje neprofitnega statusa organizacije, neposredno kreditiranje lokalnih skupnosti z izdajanjem obveznic in drugi načini, $v$ odgovor na raznovrstne, množične potrebe javnega sektorja po svežem kapitalu. 